\title{
Characteristics of termite mounds and associated acrisols in the coastal savanna zone of Ghana and impact on hydraulic conductivity
} \author{
Eric K. Nartey ${ }^{1}$, Richard J. Heck ${ }^{4}$ \\ ${ }^{1}$ Department of Soil Science, School of Agriculture, University of Ghana, Legon, Ghana; \\ *Corresponding Author: gdowuona30@hotmail.com, gdowuona@ug.edu.gh \\ ${ }^{2}$ Mineralogy Department, Natural History Museum, London, UK \\ ${ }^{3}$ Department of Earth Science, University of Ghana, Legon, Ghana \\ ${ }^{4}$ School of Environmental Sciences, University of Guelph, Guelph, Canada
}

Gabriel N. N. Dowuona ${ }^{1^{*}}$, Pearl Atwere ${ }^{1}$, W. Dubbin ${ }^{2}$, Prosper M. Nude ${ }^{3}$, Baba E. Mutala ${ }^{1}$,

Received 29 April 2012; revised 30 May 2012; accepted 12 June 2012

\section{ABSTRACT}

Characteristics of termite mounds and associated Rhodic Acrisol and Haplic Acrisol in the coastal savanna zone of Ghana and their impact on hydraulic conductivity were assessed. The texture of the mounds was sandy clay in contrast to the sandy clay loam of the surface soils. Translocation of fine to medium sized soil materials influenced the relatively higher bulk density $\left(>1.60 \mathrm{Mg} / \mathrm{m}^{3}\right)$ and contents of organic carbon, nitrogen and exchangeable bases in the mounds. Kaolinite was the dominant clay mineral with $\mathrm{pH}$ values generally below 5.3 in all the soils reflecting the weathered tropical soil environment. Dispersion ratio values, which were $<0.40$ for the mound and $>0.5$ for the surface soils, indicated greater stability of the mound due to aggregate cementing action by the termites. Estimated mound density was about $\mathbf{1 2 0}$ mounds per ha, which tied in with known groundwater reserves at the study sites. Majority of the mounds exhibited a cone-shaped morphology with heights varying between $3.05-4.00 \mathrm{~m}$ in the Rhodic Acrisol and $2.05-4.20 \mathrm{~m}$ in the Haplic Acrisol with corresponding estimated total mass of $96,361 \mathrm{~kg}$ and $54,910 \mathrm{~kg}$ per $1000 \mathrm{~m}^{2}$ land area. These estimates represented a large amount of material relative to the $25,000-26,000 \mathrm{~kg}$ of surface soil material within the same unit area. The $K_{\theta}$ in the surface soils ranged from $3.3 \times 10^{-5}$ to $5.0 \times 10^{-5}$ $\mathrm{m} / \mathrm{s}$ while the value for the mound was $\leq 0.5 \times$ $10^{-5} \mathrm{~m} / \mathrm{s}$. Lower porosity, $<40 \%$, in the mound coupled with the high bulk density and compact morphology accounted for the reduced $K_{\theta}$. Treatment of the $0-20 \mathrm{~cm}$ topsoil with mound material caused about $2-5$ fold reduction in $K_{\theta}$; the effect was more pronounced when the mound was applied on the soil surface. Improvement in water retention and nutrient availability to plants and prevention of leaching to avoid groundwater contamination are some of the positive attributes of this study.

Keywords: Aggregate Stability; Clay Mineralogy; Dispersion Ratio; Hydraulic Conductivity; Mound Morphology; Termite Mounds

\section{INTRODUCTION}

Soils of the semi-arid zones of the tropics often have a low inherent fertility due to advanced stage of weathering, leaching of soil nutrients and also rapid mineralization of organic matter [1-5]. Consequently, crop production without the addition of fertilizers leads to very low yields. Agronomic research directed towards the determination of appropriate application rates of nutrient inputs for optimum yield has not addressed the low water holding capacity, weak soil structure, and a high leaching rate of applied agrochemicals such as fertilizers and pesticides. Management strategies, which seek to increase water holding capacity, improve soil structure and indeed, reduce nutrient leaching, are therefore desirable. In a previous study, Akomaning et al. [6] investigated the role of plant residues, as an amendment, in reducing nitrate and ammonium leaching in some Acrisols of the coastal savanna zone of Ghana.

Generally, the high cost of chemical fertilizer remains a major constraint for resource-poor farmers in many parts of the tropics. Therefore, a search for economical alternatives as sources of amendment materials, to im- 
prove soil productivity, is a desirable option. Termite mounds constitute unique, but common micro-landforms that are associated with soils in the savanna zones of the tropics [7-11]. Studies on characterization of termite mounds show that they are stable and resistant to erosion [12-14], have a better productive capacity than their associated soils [15-18], are good indicators of groundwater and mineral reserves $[19,20]$ and can be rebuilt into stable microstructures [21,22].

As noted by Wood [23], termites are the most important soil fauna of the semi-arid tropics yet they are generally regarded as pests. Although research on termites has historically concentrated on pest management, some studies on the physical and chemical properties of termite mounds indicate that these micro landforms are important bioengineers [24-28]. In spite of recommendation for use of termite mounds for agronomic purposes $[13,29,30]$, application of these materials as amendment to improve the productivity of low activity clay soils in the savanna zones of the tropics, where they are dominant, has received little attention [11,17,30-32]. Quantitative data on density, volume and mass of mounds and rate of regrowth are very scanty $[11,14,22,33]$ notwithstanding some useful information such as sources of groundwater and mineral deposits that could be derived from these measurements. The aim of this study was therefore to 1) characterize some termite mounds and their associated dominant soils in the coastal savanna zone of Ghana and assess the effect of the mound material on hydraulic conductivity and 2) provide information of mound dimensions, mass of material and rate of regeneration.

\section{MATERIAL AND METHODS}

\subsection{Site Characteristics and Soils}

The study site is located within the coastal savanna zone of Ghana, which is part of the dominant ecosystem of West Africa. Total annual rainfall is about $900 \mathrm{~mm}$ and is bimodally distributed with mean monthly maxima in May and October. Relative humidity ranges between 59\% in the afternoon and $93 \%$ at night with a mean annual temperature of about $28^{\circ} \mathrm{C}$. The vegetation is grassland with substantial amounts of thickets and clumps. Quartzite and quartzitic sandstones are the underlying geological formations with evidence of fractures and groundwater reserves typical of the hydrogeology of the Togo Structural Units of Ghana [34,35]. Many bore holes tapping groundwater for use by the local community were identified at the site.

Two major soils, Rhodic Acrisol (Toje series) and Haplic Acrisol (Adenta series) located within in the coastal savanna zone of Ghana were used in the study (Figure 1). The Toje series occurs in upland positions, whereas the
Adenta series occupies mid-slope sites. Termite mounds with approximately conical geomorphological shape are common micro landforms at the study site.

\subsection{Field Investigations and Sampling}

One modal profile and a nearby termite mound on each of the two soil series were selected for characterization and sampling (Figure 2). For each soil, a profile pit was dug after which disturbed and undisturbed samples were collected from each genetic horizon. Five representative samples were taken from each mound after the surface had been carefully scrapped to get below the crusted outer layers. The mound on the Rhodic Acrisol (Toje series) was sampled from the summit at $0-80 \mathrm{~cm}$, $80-160 \mathrm{~cm}, 160-240 \mathrm{~cm}, 240-320 \mathrm{~cm}$ and $320-400$ $\mathrm{cm}$ intervals through a vertical section. Five samples were collected from the mound on the Haplic Acrisol (Adenta series) from the top at $0-30 \mathrm{~cm}, 30-60 \mathrm{~cm}, 60$ - $90 \mathrm{~cm}, 90-120 \mathrm{~cm}$ and $120-165 \mathrm{~cm}$ intervals. Undisturbed samples were collected from each of the intervals on the two mounds using core samplers $(5 \mathrm{~cm}$ diameter, $5 \mathrm{~cm}$ height). Surface samples $(0-20 \mathrm{~cm}$ depth) were also collected at $5 \mathrm{~m}$ intervals along transects from the base of the mound to the edge of the profile pits. For the Rhodic Acrisol, six samples were collected whereas three samples were obtained for the Haplic Acrisol because of the shorter distance between the mound and the profile pit. To estimate the total mass of the mound material, five other conically-shaped mounds which occurred within an area of $1000 \mathrm{~m}^{2}$ on each soil series were included in the investigation. For each of the mounds, ten core samples were randomly sampled for bulk density determination. Field data collected included vertical height and base diameter of each mound. Measurements of newly formed mounds, within the study area after destruction of the original mounds, were taken to assess the rate of regeneration.

\subsection{Laboratory Investigations}

The disturbed soil samples were air dried and ground gently to pass through a $2 \mathrm{~mm}$ sieve for analyses of selected physical and chemical properties. Laboratory analyses were carried out on the samples collected from the termite mounds, modal profiles and transects. Physical properties determined included bulk density (on the undisturbed soil cores) particle size distribution (sodium hexametaphosphate and water dispersible, respectively), soil $\mathrm{pH}$ in water and in $0.01 \mathrm{M} \mathrm{CaCl}_{2}$ (1:2 soil:solution), organic carbon, available phosphorus, exchangeable bases and exchange acidity. The clod method [36] was employed for bulk density analysis while particle size distribution in calgon $(c)$ was by the modified Bouyoucos hydrometer [37] and repeated with water dispersion $(w)$. 


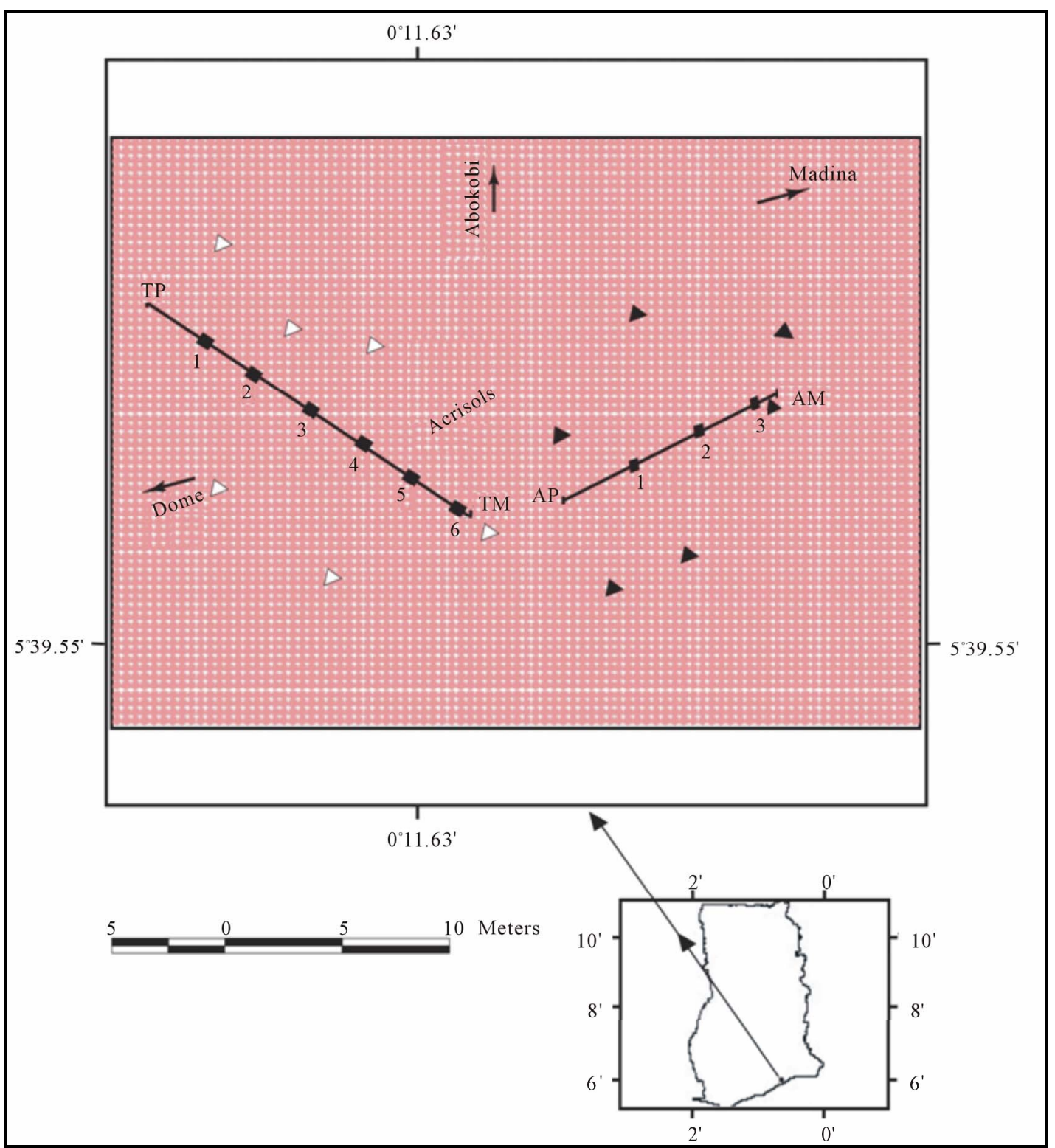

Figure 1. Study site showing location of termite mounds (TP, AM), modal profiles (TM, AP), sampling spots along transects $(\boldsymbol{\square})$ and other mounds $(\triangle, \boldsymbol{\Delta})$ used for estimation of soil mass.

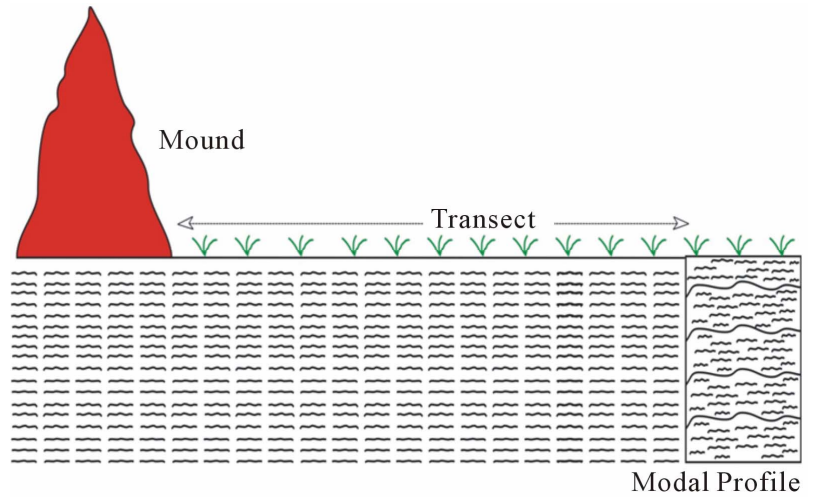

Figure 2. Schematic representation of mound, modal profile and adjacent soil.
Soil pH (1:1, soil:water and soil: $\left.0.01 \mathrm{M} \mathrm{CaCl}_{2}\right)$ was measured using a Pancitronic MV $88 \mathrm{pH}$ glass electrometer. The dry combustion method using the Carbon Analyzer (Eltra CS 500 Carbonator) was applied to determine soil organic carbon content. Total nitrogen was determined by the acid digestion Kjeldahl method [38] whereas available phosphorus was estimated by the method of Bray and Kurtz [39]. Exchangeable bases were determined by extraction with $1 \mathrm{M}$ ammonium acetate $\left(\mathrm{NH}_{4} \mathrm{OAc}, \mathrm{pH} 7\right)$ followed by analyses for $\mathrm{Ca}$ and $\mathrm{Mg}$ by atomic absorption spectrometry and $\mathrm{Na}$ and $\mathrm{K}$ by flame photometry. Exchange acidity was determined using the $\mathrm{KCl}$ extraction method [40]. Effective cation exchange capacity (ECEC) was calculated by sum of 
exchangeable bases and exchange acidity. Mineralogical composition of the clay fraction of selected samples (from the termite mounds and the soil profiles) was analysed by $\mathrm{x}$-ray diffraction $(\mathrm{CuK} \alpha)$ at the Laboratory of the Department of Mineralogy, Natural History Museum, London, UK.

\subsubsection{Hydraulic Conductivity}

Hydraulic conductivity was determined on packed columns of ground soil using the constant head method. A filter paper disc was placed at the bottom of the cylinder to prevent removal of the soil particles with the flowing water. The soil was carefully packed in the cylinder (soil column) to ensure uniformity and field bulk density and was saturated with water overnight by capillary action. A Mariotte bottle was used to maintain a constant head of water over the soil sample. At equilibrium, the quantity of water, $Q\left(\mathrm{~m}^{3}\right)$, that flowed out of the sample of length, $L(\mathrm{~m})$, and cross-sectional area, $A\left(\mathrm{~m}^{2}\right)$, for the given hydraulic-head drop, $\Delta h$, was measured for the time elapsed, $t$ (s). The hydraulic conductivity, $K_{\theta}$ was then measured using Darcy's equation as follows:

$$
Q /(A \cdot t)=-K_{\theta}(\Delta h / L)
$$

In two separate experiments, the mound material was 1) packed on top of the soil samples (in a 1:6, mound to soil mass ratio) and 2) mixed with the soil in the same ratio. Hydraulic conductivity was determined for each system. The experiment for each treatment was done in triplicates.

\subsubsection{Calculation of Dispersion Ratio}

Data from the particle size distribution were used to calculate the dispersion ratio (DR) which served as an index of aggregate stability and erodibility [41]. The DR was calculated as:

$$
\mathrm{DR}=(\% \text { silt }+\% \text { clay })_{w} /(\% \text { silt }+\% \text { clay })_{c}
$$

where " $w$ " is dispersion in water and " $c$ " is dispersion in Calgon (sodium hexametaphosphate).

\subsubsection{Calculation of Total Mass of Mound and Soil}

If one assumed that the shape of the selected termite mounds approximate to that of a cone, then the total mass of the termite mound was estimated from Eqs.3 and 4. First a volume, $V\left(\mathrm{~m}^{3}\right)$, of a cone was calculated as:

$$
V=1 / 3\left(\pi r^{2} * h\right)
$$

where $r$ is the base radius (m) and $h$ is the vertical height (m) of an assumed cone-shaped mound. Subsequently, the total mass, $M_{m}(\mathrm{~kg})$, of the bulk mound material (or soil) was calculated from Eq.4 as:

$$
M_{m}=V^{*} B D
$$

where $V$ is the volume of mound as defined in Eq.3 and $B D$ is the average bulk density $\left(\mathrm{Mg} / \mathrm{m}^{3}\right)$ value of each mound. The mass of bulk soil $\left(M_{s}\right)$ within the depth of 20 $\mathrm{cm}$ was calculated from $\mathbf{E q . 5}$ as:

$$
M_{s}=B D^{*} A^{*} d
$$

where $A=$ area $\left(1000 \mathrm{~m}^{2}\right)$ and $d$ is depth (m) of sampling of surface soils $(0.20 \mathrm{~m})$.

\section{RESULTS AND DISCUSSION}

\subsection{Morphological Characteristics}

The Rhodic Acrisol (Toje series) occurs in upland positions of the topography with slopes less than $1 \%$. The topsoil is dark reddish brown grading to red with depth. The structure is granular at the surface, with friable consistency; this changes to weak, fine subangular blocky below the surface becoming moderate to strong subangular blocky in the B-horizon and massive in the C-horizon. Soil consistency becomes firm at depths. Concretions were not encountered within the profile examined.

The Haplic Acrisol (Adenta series) occurs extensively on gentle middle slopes with site gradient of $1 \%-2 \%$. It has a profile which consists of light yellowish brown sandy clay loam topsoil with friable granular structure. The subsoil changes to yellowish brown sandy clay with subangular blocky structure and firm consistency and grades into mottled sandy clay containing few or many iron stone concretions and quartz gravel. Generally, the Toje series developed from a sedentary parent material show greater profile differentiation and relatively more advanced stage of weathering than the mid slope Adenta series, which formed from a colluvial material.

\subsection{General Physical and Chemical Properties}

\subsubsection{Particle Size Distribution and Bulk Density}

Analytical data on selected physical properties are given in Table 1. Particle size distribution using Calgon ${ }^{\circledR}$ exhibited higher clay values but lower sand and silt values as compared to those using only water as the dispersion agent. The texture of the mound on the Rhodic Acrisol (Toje series) and the Haplic Acrisol (Adenta series) is sandy clay. In the two modal soil profiles the texture varies from sandy loam (Toje series) and sandy clay loam (Adenta series) in the surface to sandy clay in the subsurface of the two soils. Textural variations in the surface soils along the transects are similar to the Ap and Aul horizons in the respective modal profiles. The fairly high amount of sand fraction in the soils is due to the coarse nature of the parent material. Lateral migration of finer material from upslope positions with subsequent 
Table 1. Analytical data of selected physical properties.

\begin{tabular}{|c|c|c|c|c|c|c|c|c|c|c|}
\hline \multirow{3}{*}{ Horizon/sample } & \multirow{3}{*}{ Depth/height } & \multirow{3}{*}{$\mathrm{BD}^{\dagger}\left(\mathrm{Mg} / \mathrm{m}^{3}\right)$} & \multicolumn{6}{|c|}{ Particle size distribution } & \multirow{3}{*}{ Texture $^{\dagger}$} & \multirow{3}{*}{$\mathrm{DR}^{\dagger}$} \\
\hline & & & $\operatorname{sand}_{w}$ & silt $_{w}$ & $\operatorname{clay}_{w}$ & $\operatorname{sand}_{c}$ & silt $_{c}$ & clay $_{c}$ & & \\
\hline & & & \multicolumn{6}{|c|}{ (\%) } & & \\
\hline \multicolumn{11}{|c|}{ Rhodic Acrisol (Toje series) } \\
\hline \multicolumn{11}{|c|}{ Profile (depth in cm) } \\
\hline Ap & $0-6$ & 1.24 & 86.2 & 11.5 & 2.3 & 75.4 & 18.1 & 7.4 & SL & 0.54 \\
\hline Au1 & $6-22$ & 1.29 & 85.2 & 11.7 & 3.1 & 72.1 & 18.0 & 9.9 & SL & 0.53 \\
\hline Bt1 & $22-46$ & 1.30 & 83.6 & 10.4 & 5.8 & 68.3 & 16.4 & 15.3 & SL & 0.51 \\
\hline Bt2 & $46-77$ & 1.35 & 83.3 & 10.4 & 6.3 & 61.2 & 12.2 & 26.6 & SCL & 0.43 \\
\hline $\mathrm{Bt} 3$ & $77-120$ & 1.40 & 81.8 & 11.5 & 6.7 & 54.5 & 19.5 & 26.0 & SC & 0.41 \\
\hline $\mathrm{BC}$ & $120-160$ & 1.36 & 80.9 & 11.9 & 7.2 & 49.8 & 11.4 & 38.8 & $\mathrm{SC}$ & 0.38 \\
\hline $\mathrm{C} 1$ & $160-196^{+}$ & 1.42 & 83.0 & 9.4 & 7.6 & 45.3 & 11.1 & 43.6 & SC & 0.31 \\
\hline \multicolumn{11}{|c|}{ Mound (height in cm from top) } \\
\hline T-M1 & $0-80$ & 1.62 & 81.8 & 11.1 & 7.1 & 52.1 & 9.2 & 38.7 & $\mathrm{SC}$ & 0.38 \\
\hline T-M2 & $80-160$ & 1.72 & 80.5 & 12.5 & 7.0 & 49.0 & 8.7 & 42.3 & $\mathrm{SC}$ & 0.38 \\
\hline T-M3 & $160-240$ & 1.71 & 80.6 & 12.1 & 7.3 & 52.2 & 9.1 & 38.7 & $\mathrm{SC}$ & 0.41 \\
\hline T-M4 & $240-320$ & 1.63 & 82.7 & 10.5 & 6.8 & 52.8 & 9.1 & 38.1 & $\mathrm{SC}$ & 0.37 \\
\hline T-M5 & $320-400$ & 1.60 & 81.6 & 11.2 & 7.2 & & & & & \\
\hline \multicolumn{11}{|c|}{ Transect (distance in m) } \\
\hline $\mathrm{T}-\mathrm{T} 1$ & 5 & 1.22 & 80.7 & 17.0 & 2.3 & 64.9 & 4.2 & 30.9 & SL & 0.55 \\
\hline $\mathrm{T}-\mathrm{T} 2$ & 15 & 1.21 & 78.1 & 18.8 & 3.1 & 59.7 & 5.4 & 34.9 & SL & 0.54 \\
\hline T-T3 & 20 & 1.20 & 79.1 & 18.8 & 2.1 & 63.7 & 5.7 & 30.6 & SL & 0.56 \\
\hline $\mathrm{T}-\mathrm{T} 4$ & 25 & 1.32 & 80.8 & 16.8 & 2.4 & 63.8 & 5.3 & 30.9 & SL & 0.53 \\
\hline $\mathrm{T}-\mathrm{T} 5$ & 30 & 1.26 & 80.0 & 17.5 & 2.5 & 63.0 & 5.2 & 31.8 & SL & 0.54 \\
\hline T-T6 & 35 & 1.23 & 80.8 & 16.9 & 2.3 & 64.4 & 5.0 & 30.6 & SL & 0.54 \\
\hline \multicolumn{11}{|c|}{ Haplic Acrisol (Adenta series) } \\
\hline \multicolumn{11}{|c|}{ Profile (depth in cm) } \\
\hline Ap & $0-15$ & 1.31 & 81.0 & 16.6 & 2.4 & 64.8 & 9.4 & 25.8 & $\mathrm{SCL}$ & 0.54 \\
\hline Aul & $15-27$ & 1.42 & 79.1 & 18.1 & 2.8 & 61.2 & 11.4 & 27.4 & SCL & 0.54 \\
\hline BA & $27-42$ & 1.59 & 78.7 & 18.2 & 3.1 & 58.3 & 8.5 & 33.2 & SCL & 0.51 \\
\hline Bt1 & $42-60$ & 1.61 & 76.7 & 20.0 & 3.3 & 51.4 & 11.2 & 37.4 & $\mathrm{SC}$ & 0.48 \\
\hline Btc2 & $60-90$ & 1.71 & 81.2 & 14.7 & 4.1 & 49.3 & 9.9 & 40.8 & $\mathrm{SC}$ & 0.37 \\
\hline Btc3 & $90-120$ & 1.73 & 82.1 & 13.6 & 4.3 & 48.9 & 7.5 & 36.6 & $\mathrm{SC}$ & 0.35 \\
\hline $\mathrm{BC}$ & $120-150^{+}$ & 1.74 & 82.8 & 12.4 & 4.8 & 46.2 & 9.1 & 44.7 & SC & 0.32 \\
\hline \multicolumn{11}{|c|}{ Mound (height in $\mathrm{cm}$ from top) } \\
\hline A-M1 & $0-30$ & 1.69 & 80.6 & 12.3 & 7.1 & 50.2 & 6.6 & 43.2 & $\mathrm{SC}$ & 0.39 \\
\hline A-M2 & $30-60$ & 1.73 & 82.1 & 9.4 & 8.5 & 52.0 & 4.6 & 43.4 & $\mathrm{SC}$ & 0.37 \\
\hline A-M3 & $60-90$ & 1.74 & 80.8 & 12.9 & 6.3 & 48.0 & 8.4 & 43.6 & SC & 0.37 \\
\hline A-M4 & $90-120$ & 1.71 & 79.8 & 13.1 & 7.1 & 45.5 & 5.2 & 49.3 & $\mathrm{SC}$ & 0.37 \\
\hline A-M5 & $120-165$ & 1.75 & 81.2 & 11.2 & 7.6 & 45.9 & 9.7 & 44.4 & $\mathrm{SC}$ & 0.35 \\
\hline \multicolumn{11}{|c|}{ Transect (distance in $\mathbf{m}$ ) } \\
\hline A-T1 & 5 & 1.30 & 80.0 & 16.6 & 3.4 & 65.1 & 9.7 & 25.2 & SCL & 0.57 \\
\hline A-T2 & 10 & 1.29 & 81.0 & 15.3 & 3.7 & 64.8 & 9.1 & 26.1 & SCL & 0.54 \\
\hline A-T3 & 15 & 1.31 & 81.5 & 14.9 & 3.6 & 66.4 & 6.8 & 26.8 & SCL & 0.55 \\
\hline
\end{tabular}

${ }^{\dagger} \mathrm{BD}=$ bulk density; $\mathrm{SCL}=$ sandy clay loam; $\mathrm{SC}=$ sandy clay; $\mathrm{SL}=$ sandy loam; $\mathrm{DR}=$ dispersive ratio; ${ }^{\dagger} \mathrm{w}=$ dispersion of soil particles in water; $\mathrm{c}=$ dispersion of soil particles with calgon addition. 
accumulation at mid-slope sites might account for the relatively higher clay content in the topsoil of the Adenta series.

It is apparent from the data that the textures of the mound and the subsoil of the modal profiles are similar and tend to confirm previous observations elsewhere that termite mounds are subsoil materials that have been brought to the surface by termites $[7,22,24,32,42]$. The relatively greater clay contents in the mounds than their respective associated soils are similar to other research findings $[11,25,27,28,43]$ and shows preference for the finer soil fraction (clay) by termites for the construction of these micro landforms.

Bulk density increased with depth from 1.24 to 1.42 $\mathrm{Mg} / \mathrm{m}^{3}$ with increasing depth in the Rhodic Acrisol profile. In the Haplic Acrisol profile, bulk density increased with depth from 1.31 to $1.74 \mathrm{Mg} / \mathrm{m}^{3}$, which might be attributed to the compact nature of the subsoil. The mound has a relatively higher bulk density, especially in the Rhodic Acrisol than the associated surface soils. For the Rhodic Acrisol, bulk density values were generally similar to those of the mound, especially in the subsoil thus emphasizing the fact that mounds have a subsoil property influencing it. Termite mounds in savanna landscapes of Africa are noted to have higher bulk density than the adjacent soil because the termites repack the soil to form dense hard protective layers [44,45] likely from cementation by organo-mineral complexes in the intestinal tracts of the insects. Our study tends to confirm that termites modify soil texture and bulk density through translocation of soil material, reconstruction of eroded surface soil and preferential movement of fine and medium sized particles all of which change bulk density, texture and other physical properties.

\subsubsection{Chemical Properties}

Results of analyses of selected chemical properties are given in Table 2. All the soils are acidic with $\mathrm{pH}$ values determined in $0.01 \mathrm{M} \mathrm{CaCl}_{2}$ lower than those determined in water, making the net change in $\mathrm{pH}$ negative. This suggests that the soils have a net negative charge that may serve as potential sites for adsorption of positively charged compounds.

Organic carbon (OC) content in the mound and associated soils was very low and generally decreases with depth in the two modal profiles. In the Rhodic Acrisol, the OC content of the mound and associated topsoils was similar and seems to agree with the findings in some savanna grassland soils $[11,46]$. The OC content in the mound on the Haplic Acrisol $(6.8$ to $7.7 \mathrm{~g} / \mathrm{kg})$ is greater than that of the associated surface soils on the transect $(5.9$ to $6.3 \mathrm{~g} / \mathrm{kg}$ ) and the profile ( 3.8 to $5.9 \mathrm{~g} / \mathrm{kg}$ ). Compared to the subsoil, the mounds showed relatively greater organic carbon content at each study site. Higher levels of OC in termite mounds were recorded in mounds than their associated soils in previous studies $[13,41,47$, $48]$.

The greater OC content in the mound is probably due to activities of termites when they bring subsoil mixed with organic material to the surface, thus accelerating the incorporation of humus into the soil [49]. Mixing of subsoil with surface soil and addition of OC during passage of soil through the gut of the termites, as noted in studies elsewhere in the tropics [49-51], may account for this observation. The generally low OC contents of the soils are characteristic of soils in semiarid ecosystems where the high rate of mineralization does not allow for greater accumulation of carbon. However, the relatively greater OC content of the mounds may serve a useful purpose for plant nutrition in these soils which have a low inherent fertility status.

Total $\mathrm{N}$ contents are generally low in the mounds and associated soils and follow trends in variations similar to OC contents. Broad ratings of nitrogen measurements in soils were described by Landon [52] as very high $(>10$ $\mathrm{g} / \mathrm{kg})$, high $(5-10 \mathrm{~g} / \mathrm{kg})$, medium $(2-5 \mathrm{~g} / \mathrm{kg})$, low (1 - 2 $\mathrm{g} / \mathrm{kg}$ ) and very low $(<1 \mathrm{~g} / \mathrm{kg})$. On this basis, our data confirm that generally the $\mathrm{N}$ content of the mound and profile samples are low. Nitrogen content in the Haplic Acrisol profile is typically very low in N. The narrow $\mathrm{C}: \mathrm{N}$ ratios of the soils confirm the high rate of decomposition of organic matter. Available P is generally low in all the soils and decreases with depth in the two modal profiles. The low level of this nutrient element is characteristic of soils in the savanna zones of Africa due to the low organic matter content [53]. More importantly, apatite, the mineral source of phosphorus, is very low in tropical soils. The relatively higher AP contents in the transect soils might be attributed to phosphorus bound to organic matter.

Exchangeable bases were low in mounds and associated soils due to the weathered tropical environment. Calcium and $\mathrm{Mg}$ account for more than $70 \%$ of cations at exchange sites. Exchange acidity values in the mound and associated soils reflect the recorded $\mathrm{pH}$ values. The values in the termite mounds are relatively higher than their associated soils; these values are generally greater in the Rhodic Acrisol profile, mound and transect samples than their respective counterparts in the Haplic Acrisol. Earlier studies elsewhere had also noted relative $\mathrm{Ca}$ and $\mathrm{Mg}$ enrichments in mounds [54,55] attributable to cation-clay accumulation in the subsoil where the mound material originated.

Increasing exchange acidity values are attributed to increasing leaching and weathering in tropical environments. It would seem that variation in exchange acidity gives an indication that the mound is relatively more weathered than the associated soils. Furthermore, the 
Table 2. Analytical data of selected chemical properties ${ }^{\dagger}$.

\begin{tabular}{|c|c|c|c|c|c|c|c|c|c|c|c|c|c|c|}
\hline \multirow{3}{*}{ Horizon/sample } & \multirow{3}{*}{ Depth/height } & \multirow{3}{*}{$\mathrm{pHw}$} & \multirow{3}{*}{$\mathrm{pHs}$} & \multirow{2}{*}{ O.C. } & \multirow{2}{*}{$\mathrm{TN}$} & \multirow{2}{*}{$\mathrm{AP}$} & \multirow{2}{*}{$\mathrm{C}: \mathrm{N}$} & \multicolumn{4}{|c|}{ Exchangeable bases } & \multirow{2}{*}{ TEB } & \multirow{2}{*}{ Ex. Ac } & \multirow{2}{*}{ ECEC } \\
\hline & & & & & & & & $\mathrm{Ca}$ & $\mathrm{Mg}$ & $\mathrm{Na}$ & $\mathrm{K}$ & & & \\
\hline & & & & \multicolumn{2}{|c|}{$(\mathrm{g} / \mathrm{kg})$} & \multicolumn{2}{|c|}{$(\mathrm{mg} / \mathrm{kg})$} & \multicolumn{7}{|c|}{$(\mathrm{cmol} / \mathrm{kg})$} \\
\hline \multicolumn{15}{|c|}{ Rhodic Acrisol (Toje series) } \\
\hline \multicolumn{15}{|c|}{ Profile (depth in cm) } \\
\hline Ap & $0-6$ & 4.4 & 4.5 & 8.7 & 1.52 & 5.25 & 5.7 & 4.32 & 1.91 & 0.11 & 0.26 & 6.60 & 0.30 & 6.90 \\
\hline Au1 & $6-22$ & 4.8 & 4.4 & 3.0 & 1.43 & 4.53 & 2.1 & 4.08 & 1.45 & 0.10 & 0.24 & 5.87 & 0.20 & 6.07 \\
\hline Bt1 & $22-46$ & 4.7 & 4.2 & 3.2 & 1.34 & 2.22 & 2.4 & 3.86 & 1.01 & 0.08 & 0.19 & 5.14 & 0.29 & 5.43 \\
\hline Bt2 & $46-77$ & 4.7 & 4.2 & 3.2 & 1.20 & 1.71 & 2.7 & 3.44 & 0.70 & 0.08 & 0.17 & 4.39 & 0.20 & 4.59 \\
\hline Bt3 & $77-120$ & 4.6 & 4.1 & 2.2 & 1.24 & 1.49 & 1.8 & 3.22 & 0.45 & 0.09 & 0.15 & 3.91 & 0.26 & 4.17 \\
\hline $\mathrm{BC}$ & $120-160$ & 4.5 & 4.0 & 1.4 & 1.05 & 1.37 & 1.3 & 3.44 & 0.26 & 0.08 & 0.11 & 3.89 & 0.22 & 4.11 \\
\hline $\mathrm{C} 1$ & $160-196^{+}$ & 4.5 & 4.0 & 1.3 & 0.89 & 1.28 & 1.5 & 2.62 & 0.20 & 0.07 & 0.11 & 3.00 & 0.39 & 3.29 \\
\hline \multicolumn{15}{|c|}{ Mound (height in cm from top) } \\
\hline T-M1 & $0-80$ & 5.9 & 5.5 & 7.1 & 1.55 & 3.49 & 4.6 & 5.04 & 1.80 & 0.16 & 0.30 & 7.30 & 0.42 & 7.72 \\
\hline T-M2 & $80-160$ & 5.9 & 5.4 & 7.5 & 1.38 & 2.45 & 5.4 & 4.92 & 1.65 & 0.21 & 0.29 & 7.07 & 0.33 & 7.40 \\
\hline T-M3 & $160-240$ & 6.3 & 5.9 & 6.7 & 1.21 & 2.23 & 5.5 & 4.28 & 1.60 & 0.20 & 0.25 & 6.33 & 0.34 & 6.67 \\
\hline T-M4 & $240-320$ & 5.9 & 5.5 & 6.2 & 1.47 & 2.55 & 4.2 & 5.23 & 2.01 & 0.15 & 0.32 & 7.71 & 0.43 & 8.14 \\
\hline T-M5 & $320-400$ & 6.3 & 5.7 & 6.4 & 1.37 & 3.57 & 4.7 & 4.80 & 1.72 & 0.16 & 0.26 & 6.94 & 0.30 & 7.24 \\
\hline \multicolumn{15}{|c|}{ Transect (distance in $\mathbf{m})^{\dagger}$} \\
\hline $\mathrm{T}-\mathrm{T} 1$ & 5 & 4.9 & 4.4 & 7.1 & 1.67 & 5.82 & 4.3 & 4.28 & 1.80 & 0.13 & 0.41 & 6.62 & 0.33 & 6.95 \\
\hline $\mathrm{T}-\mathrm{T} 2$ & 15 & 4.7 & 4.3 & 8.8 & 1.78 & 5.73 & 4.9 & 3.90 & 1.72 & 0.12 & 0.37 & 6.11 & 0.29 & 6.40 \\
\hline T-T3 & 20 & 5.2 & 4.3 & 8.0 & 1.66 & 5.84 & 4.8 & 4.06 & 1.71 & 0.10 & 0.38 & 6.25 & 0.31 & 6.56 \\
\hline $\mathrm{T}-\mathrm{T} 4$ & 25 & 4.9 & 4.4 & 6.3 & 1.90 & 5.52 & 3.3 & 4.26 & 1.76 & 0.14 & 0.39 & 6.55 & 0.28 & 6.83 \\
\hline T-T5 & 30 & 4.9 & 4.4 & 7.6 & 1.87 & 5.81 & 4.1 & 4.34 & 1.90 & 0.12 & 0.37 & 6.73 & 0.35 & 7.08 \\
\hline T-T6 & 35 & 4.9 & 4.4 & 8.3 & 1.91 & 5.63 & 4.4 & 4.12 & 1.82 & 0.13 & 0.39 & 6.46 & 0.27 & 6.73 \\
\hline
\end{tabular}

Profile (depth in cm)

$\begin{array}{ccccccccccccccc}\text { Ap } & 0-15 & 5.3 & 4.9 & 5.9 & 0.98 & 4.08 & 6.0 & 3.68 & 1.14 & 0.14 & 0.21 & 5.17 & 0.29 & 5.46 \\ \text { Au1 } & 15-27 & 5.2 & 4.8 & 4.8 & 0.97 & 2.67 & 5.0 & 3.60 & 1.04 & 0.13 & 0.20 & 4.97 & 0.25 & 5.22 \\ \text { BA } & 27-42 & 5.1 & 4.7 & 5.2 & 0.93 & 1.82 & 5.6 & 3.32 & 0.95 & 0.09 & 0.18 & 4.54 & 0.21 & 4.75 \\ \text { Bt1 } & 42-60 & 5.0 & 4.5 & 3.8 & 0.81 & 1.74 & 4.7 & 2.56 & 0.90 & 0.09 & 0.16 & 3.71 & 0.20 & 3.91 \\ \text { Bt2 } & 60-90 & 4.9 & 4.4 & 4.4 & 0.81 & 1.88 & 5.4 & 2.52 & 0.86 & 0.08 & 0.11 & 3.57 & 0.22 & 3.79 \\ \text { Bt3 } & 90-120 & 4.8 & 4.3 & 4.4 & 0.78 & 1.73 & 5.6 & 2.48 & 0.85 & 0.07 & 0.11 & 3.51 & 0.21 & 3.72 \\ \text { BC } & 120-150^{+} & 4.6 & 4.1 & 3.5 & 0.74 & 1.39 & 4.7 & 2.44 & 0.66 & 0.07 & 0.09 & 3.26 & 0.19 & 3.45\end{array}$

Mound (height in cm from top)

\begin{tabular}{|c|c|c|c|c|c|c|c|c|c|c|c|c|c|c|}
\hline A-M1 & $0-30$ & 4.9 & 4.5 & 7.6 & 1.66 & 2.42 & 4.6 & 4.02 & 1.49 & 0.20 & 0.26 & 5.97 & 0.39 & 6.36 \\
\hline A-M2 & $30-60$ & 5.0 & 4.6 & 7.7 & 1.64 & 2.45 & 4.7 & 3.48 & 1.40 & 0.18 & 0.26 & 5.32 & 0.29 & 5.61 \\
\hline A-M3 & $60-90$ & 4.9 & 4.4 & 6.8 & 1.69 & 2.11 & 4.0 & 3.80 & 1.46 & 0.19 & 0.25 & 5.70 & 0.31 & 6.01 \\
\hline A-M4 & $90-120$ & 5.2 & 4.7 & 7.6 & 1.58 & 2.32 & 4.8 & 3.92 & 1.48 & 0.23 & 0.23 & 5.86 & 0.32 & 6.18 \\
\hline A-M5 & $120-165$ & 5.0 & 4.6 & 7.0 & 1.42 & 2.88 & 4.9 & 3.64 & 1.42 & 0.18 & 0.23 & 5.47 & 0.31 & 5.78 \\
\hline
\end{tabular}

Transect (distance in $\mathbf{m})^{\dagger}$

\begin{tabular}{lllllllllllllll} 
A-T1 & 5 & 5.3 & 4.9 & 5.9 & 1.97 & 5.27 & 3.0 & 3.80 & 1.12 & 0.15 & 0.22 & 5.29 & 0.30 & 5.59 \\
A-T2 & 10 & 4.4 & 4.9 & 6.3 & 1.97 & 5.02 & 3.2 & 3.42 & 1.15 & 0.16 & 0.22 & 4.95 & 0.29 & 5.24 \\
A-T3 & 15 & 5.3 & 4.9 & 6.0 & 1.46 & 5.06 & 4.1 & 3.40 & 1.10 & 0.14 & 0.21 & 4.85 & 0.28 & 5.13 \\
\hline
\end{tabular}

$\dot{\dagger}=$ top soil sampled at $0-20 \mathrm{~cm}$ depth at the distance intervals in metres (between the location of mound and profile pits) starting from the profile pit i.e. 0 - 5 $\mathrm{m} ;{ }^{\dagger} \mathrm{pHw}=\mathrm{pH}$ in water; $\mathrm{pHs}=\mathrm{pH}$ in $0.01 \mathrm{M} \mathrm{CaCl}_{2} ; \mathrm{O} . \mathrm{C} .=$ organic carbon; $\mathrm{TN}=$ total nitrogen; $\mathrm{AP}=$ available phosphorus; TEB $=$ sum of exchangeable bases; Ex. Ac = exchange acidity; ECEC $=$ effective cation exchange capacity. 
values also confirm the greater profile maturity of the Toje series. The effective cation exchange capacity (ECEC) values of the Toje series (soils and mound) are greater than the ECEC of the Adenta series. The generally low ECEC suggests dominance of low activity clays.

\subsection{Aggregate Stability and Mineralogy}

Analytical data on dispersion ratio (DR) are presented in Table 1. Dispersion ratio, an index used to estimate the stability of soil aggregates, indicates the ease with which silt and clay particles go into suspension. As noted in research on aggregate stability by other workers [47, 56-59], the DR is a function of organic matter content of soils. A lower DR value means a greater stability of soil and hence less erodibility [48].

Dispersion ratios were lower in the mounds (DR < $0.41)$ than their respective associated soils, especially the topsoils (DR > 0.5). However, DR values of the mounds were generally similar to those of the subsoil of the profiles. It is apparent that the action of termites has led to a greater stability of aggregates in the mounds. Evidence that exchangeable cations (especially $\mathrm{Ca}^{2+}$ ) and organic particles in the intestinal tract of termites act as cementing materials in the formation and stabilization of micro-aggregates in mounds [60] may underscore the role of termites in enhancing structural stability of soils. Translocation of fine soil material tends to change soil bulk density, porosity and other physical properties of soils [45] as noted in our research.

In a study of structural stability of termite mounds elsewhere in the tropics [13] it was observed that clay content, more than organic matter, enhanced the stability of mound soils. In this study, therefore, it is apparent that the relatively higher clay content in the termite mounds could lead to decrease in pore sizes and transmission of water (which will be discussed in Section 3.4) and contribute, in part, to the greater structural stability. Our observation tends to agree with results of other studies $[14,18,26,28]$ which indicated that shear strength of termite mounds were greater than surrounding soils as a result of decreasing water content apparently from reduced pore size distributions.

Random powder x-ray diffraction patterns of the termite mounds and associated soils are shown in Figures 3 and 4 . The analyses show that kaolinite is the dominant clay mineral, which is consistent with the tropical environment and the low effective cation exchange capacity. Peaks referable to quartz are prominent in all the soils. Peak intensity is relatively greater in the mound samples (Figures 3(a) and 4(a) than their associated soils (Figures 3(b), (c) and 4(b), (c)) and generally in the Rhodic Acrisol (Figure 3) than in the Haplic Acrisol (Figure 4). Similar mineralogical composition in termite mounds has been

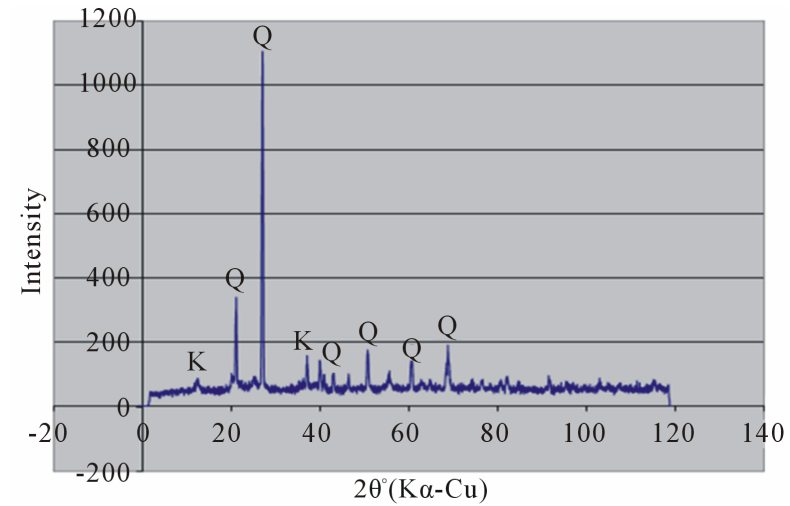

(a)

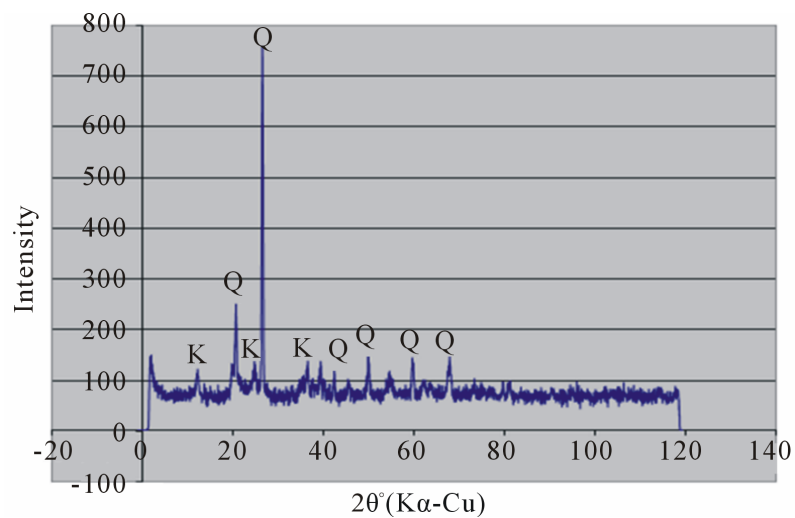

(b)

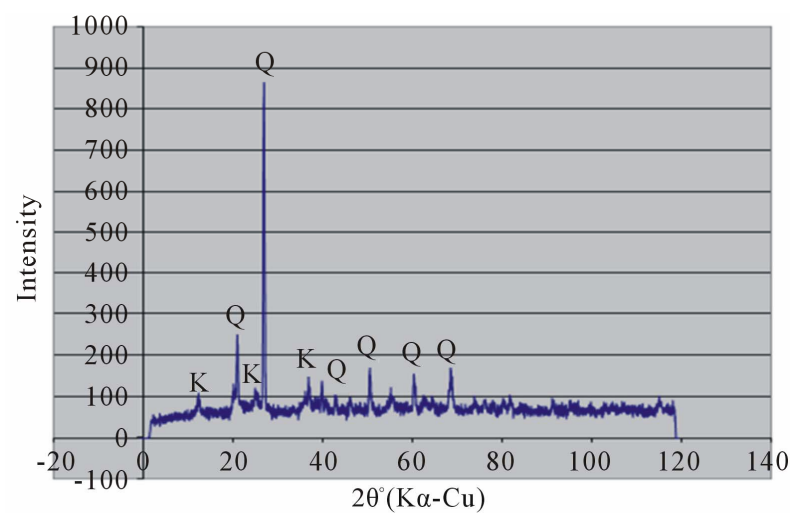

(c)

Figure 3. X-ray diffraction patterns of random clay samples of termite mound (a); and associated soil profile at $50 \mathrm{~cm}$ depth (b); and $120 \mathrm{~cm}$ depth (c) on the Rhodic Acrisol.

reported elsewhere in the tropics $[11,17,28,61]$. Termites play a critical role in the transformation of primary minerals to finely crystallized kaolinites. It is therefore postulated that a combined effect of kaolinite, quartz and organic matter brings about the greater stability of termite mounds. Kaolinite serves as the mortar, quartz as the aggregate units and organic matter as the plaster similar to conventional building material. 


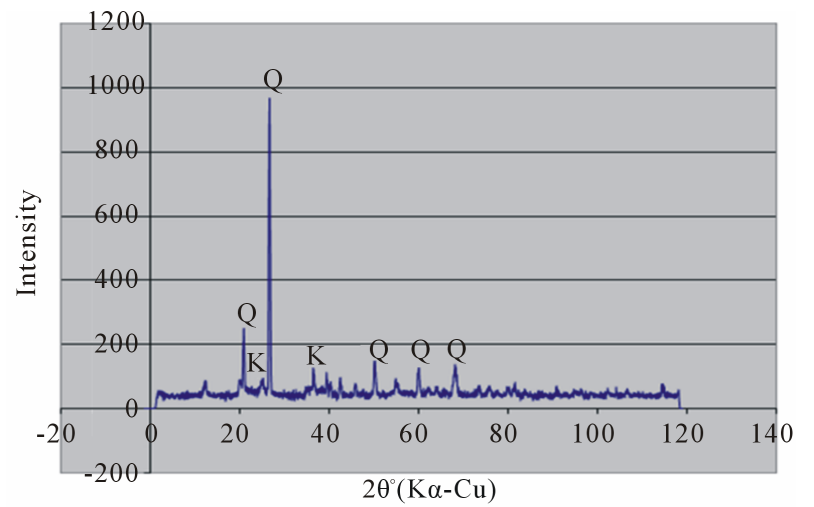

(a)

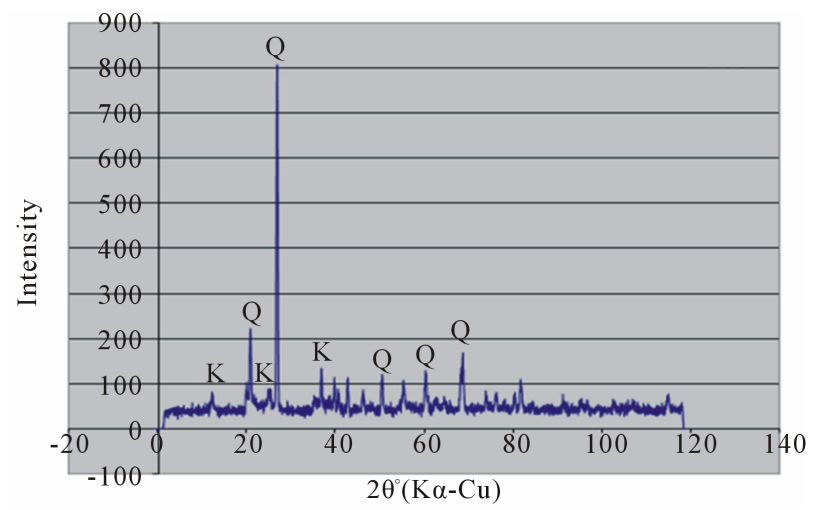

(b)

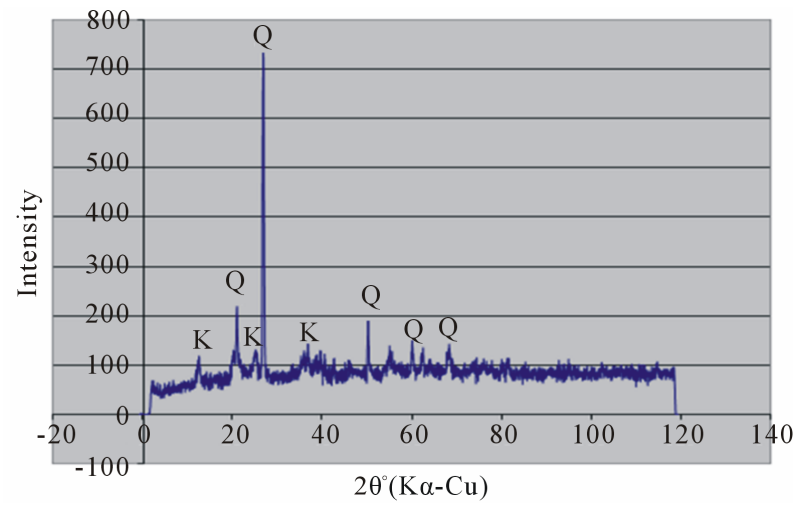

(c)

Figure 4. X-ray diffraction patterns of random clay samples of termite mound (a); and associated soil profile at $50 \mathrm{~cm}$ depth (b); and $120 \mathrm{~cm}$ depth (c) on the Haplic Acrisols.

\subsection{Characteristics of Mounds}

This section presents relevant data and discussion on mound morphology (architecture), abundance, mass of mound and soil material and regeneration of mounds. Morphological characteristics indicated that majority of the mounds at the study sites are conical in shape while a few others have a "cathedral" configuration (Figures 5(a) and (b)). They are compact and sealed at the surface with some internal macropores in all of them to allow for

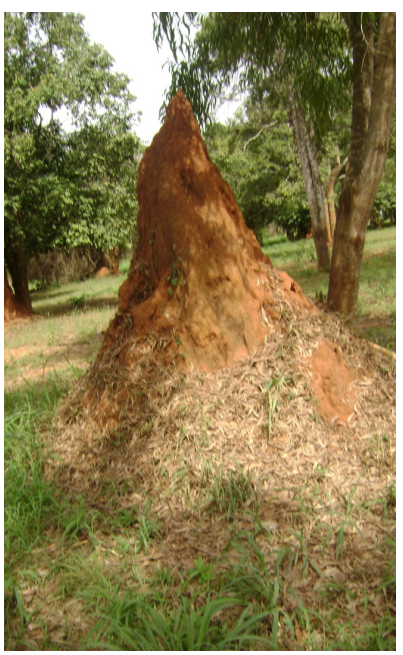

(a)

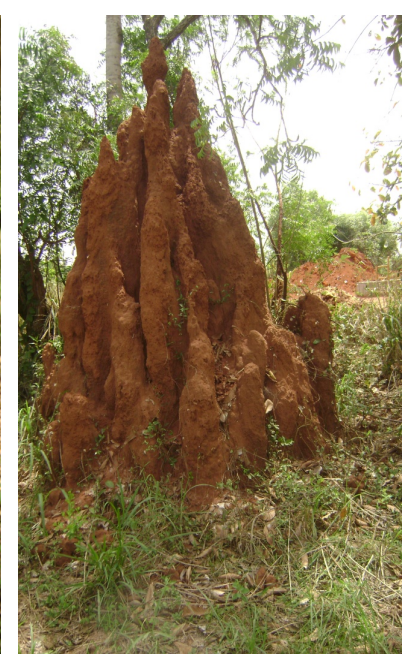

(b)

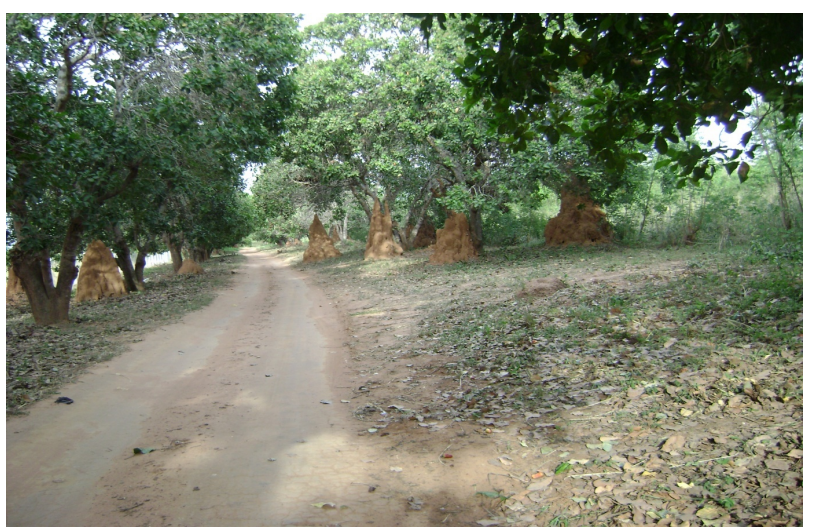

(c)

Figure 5. Morphology of mounds: conical (a); and cathedral (b) types, and density (c).

ventilation and regulation of temperature. The colour of the mounds on each soil is similar to the colour of the subsoil of each associated soil; reddish brown to red in the Rhodic Acrisol and yellowish brown in the Haplic Acrisol confirm that materials for the construction of mounds are from the subsoils. Data on height of each mound, base diameter and mean bulk density are presented in Table 3. Mounds on the Rhodic Acrisols are generally higher $(3.05-4.00 \mathrm{~m})$ with corresponding greater base diameter $(2.05-4.20 \mathrm{~m})$ than those on the Haplic Acrisol (1.65 - $4.20 \mathrm{~m}$ high and $2.05-3.20 \mathrm{~m}$ diameter). Relatively lower mound dimensions have been reported in similar semi-arid environments in Northern Namibia [22].

Data on total soil mass of mounds on each soil series are also presented in Table 3. For the Rhodic Acrisol (Toje series), the mass of the six selected mounds ranged from $7265 \mathrm{~kg}$ to $33,133 \mathrm{~kg}$ with a total mass of 96,361 $\mathrm{kg}$. The mass of the mounds on the Haplic Acrisol (Adenta series) also varied from $3124 \mathrm{~kg}$ to $19,262 \mathrm{~kg}$, 
which summed up to $54,910 \mathrm{~kg}$. The calculated total mass of soil from a depth of $0.2 \mathrm{~m}$ is $250,000 \mathrm{~kg} / \mathrm{ha}$ and $260,000 \mathrm{~kg} / \mathrm{ha}$, respectively, for Toje series and Adenta series (Table 4). For an area of $1000 \mathrm{~m}^{2}$ the soil mass would be $25,000 \mathrm{~kg}$ and $26,000 \mathrm{~kg}$ for the two respective soils. This means that the mound samples would be far greater than the total soil mass at a depth of $0.2 \mathrm{~m}$ at each respective site highlighting the large amount of mound material that would be available for use as amendment material. Kaschuk et al., [11] employed similar procedures to measure the amount of mound material in natural grasslands of Brazil. These authors noted that termite activity in different locations was associated with transportation of large volume of soil material, which varied from $20.9 \mathrm{~m}^{3} /$ ha to $136 \mathrm{~m}^{3} / \mathrm{h}$.

In our current study, it is apparent that the greater

Table 3. Field data and estimated total soil mass of each mound within an area of $1000 \mathrm{~m}^{2}$.

\begin{tabular}{ccccc}
\hline Sample & $\begin{array}{c}\text { Height } \\
(\mathrm{m})\end{array}$ & $\begin{array}{c}\text { Diameter } \\
(\mathrm{m})\end{array}$ & $\begin{array}{c}\mathrm{BD}^{\dagger} \\
\left(\mathrm{Mg} / \mathrm{m}^{3}\right)\end{array}$ & $\begin{array}{c}\text { Soil mass } \\
(\mathrm{kg})\end{array}$ \\
\hline T-M1 & 4.00 & 2.05 & 1.65 & 7265 \\
T-M2 & 3.75 & 2.20 & 1.72 & 8177 \\
T-M3 & 5.05 & 3.85 & 1.69 & 33,133 \\
T-M4 & 3.05 & 2.80 & 1.74 & 10,898 \\
T-M5 & 4.30 & 2.58 & 1.73 & 12,969 \\
T-M6 & 3.10 & 4.20 & 1.67 & 23,919 \\
& Haplic Acrisol (Adenta series) & \\
A-M1 & 1.65 & 2.05 & 1.72 & 3124 \\
A-M2 & 1.95 & 2.20 & 1.70 & 4202 \\
A-M3 & 3.10 & 2.70 & 1.69 & 10,003 \\
A-M4 & 2.80 & 2.05 & 1.68 & 5178 \\
A-M5 & 4.20 & 3.20 & 1.71 & 19,262 \\
A-M6 & 3.55 & 2.85 & 1.74 & 13,141 \\
\hline BD = bulk density (mean of 10 samples per mound); ${ }^{\ddagger}=$ calculated from \\
Eq.4.
\end{tabular}

Table 4. Calculated total soil mass at each study site.

\begin{tabular}{ccccc}
\hline Site & $\begin{array}{c}\text { Depth } \\
(\mathrm{m})\end{array}$ & $\begin{array}{c}\text { Area } \\
\left(\mathrm{m}^{2}\right)\end{array}$ & $\begin{array}{c}\mathrm{BD}^{\dagger} \\
\left(\mathrm{Mg} / \mathrm{m}^{3}\right)\end{array}$ & $\begin{array}{c}\text { Soil mass } \\
(\mathrm{kg} / \mathrm{ha})\end{array}$ \\
\hline \multicolumn{5}{c}{ Rhodic Acrisol (Toje series) } \\
1 & 0.20 & 1000 & 1.25 & 250,000 \\
& \multicolumn{4}{c}{ Haplic Acrisol (Adenta series) } \\
& 0.20 & 1000 & 1.30 & 260,000 \\
\hline
\end{tabular}

${ }^{\dagger} \mathrm{BD}=$ bulk density (mean of 10 surface samples); ${ }^{\ddagger}=$ calculated from Eq.5. volume and mass of soil material in the mounds on the Rhodic Acrisol were influenced by the relatively large non-compact subsoil available to the termites. These amounts of material coupled with the stability of the mounds also give a positive indication that application of mound samples on the soil annually will improve structural stability of the soils. From the standpoint of soil conservation this can be significant since it provides readily available material to reduce soil erosion by run-off and maintain the productivity levels of the soils.

On the basis of the number of mounds used at the study site and other mounds counted during the field work, an average of 12 mounds were recorded per 1000 $\mathrm{m}^{2}$ land area, which would translate into an average of 120 mounds per ha. Available data indicate that the density of mounds in the guinea savanna zone of Ghana varied from 70 to 118 per ha [33]. From this observation it can deduced that the density of mounds in our study is appreciably high. However, greater mound densities have been recorded in other tropical grasslands [11] and forest ecosystems [14].

As indicated in Section 2.2, termite mounds were broken down and the debris removed. To ascertain the rate of regeneration, measurement of newly formed mounds were taken 14 days after the destruction. The following respective heights and base diameters of 4 mounds were obtained (Figure 6): $1.3 \mathrm{~m}$ and $3.0 \mathrm{~m}$ (a); $2.0 \mathrm{~m}$ and 3.0 $\mathrm{m}$ (b); and $1.6 \mathrm{~m}$ and $2.5 \mathrm{~m}$ (c) and $1.4 \mathrm{~m}$ and $1.5 \mathrm{~m}$ (not shown). Another mound (Figure 6(d)) measured showed a height of $4.0 \mathrm{~m}$ and base diameter of $4.0 \mathrm{~m}$ after destruction in 100 days. Regeneration of the mounds on the Rhodic Acrisol was relatively more marked. Perhaps the large volume of fine to medium size soil material enhanced faster rate of regrowth. Generally, previous data on fast growth or regeneration of mounds as noted in this study are quite rare in the literature; previous study indicated that $0.61 \mathrm{~m}$ high mound was rebuilt within one month [62].

The above observations may have some useful implications for natural resource utilization. Termite mounds have been identified as important hydrological indicators elsewhere $[20,63]$. It was noted that in the humid tropical regions of Congo (Katanga province) and the drier areas of India, occurrence of termite mounds was associated with spring water sources [63]. Consistent with this evidence, many bore holes to tap groundwater reserves for the local university community were identified at the study site. The abundance of mounds at the study site may therefore confirm the correlation that exists with groundwater sources. Furthermore, the observation that water availability is essential in the construction of mounds might be a plausible reason for the abundance of well-formed mounds and the fast rate of generation at the study sites. Termites normally use readily available source 


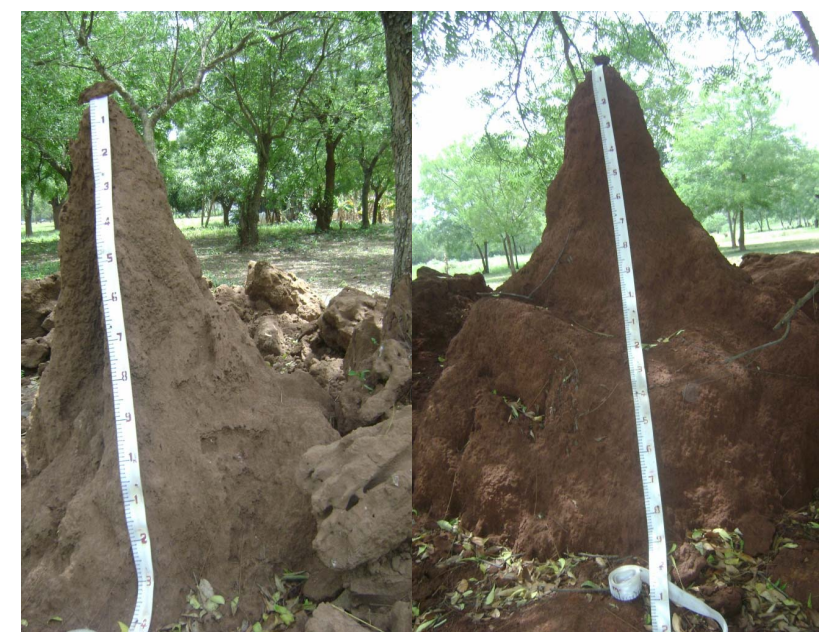

(a)

(b)

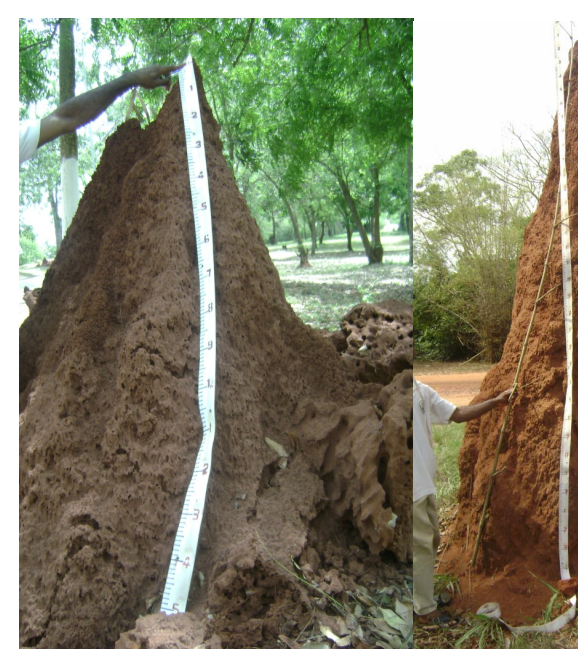

(c)

(d)

Figure 6. Regeneration of mounds to varying heights in 14 days (a, b and c) and 100 days (d).

of water such as atmospheric precipitation and water close to the ground surface for their metabolic activities including mound construction. Considering the moisture-stress environment at the study site, it is likely that the underground water, which is noted to be less than 40 $\mathrm{m}$, serves as a reliable water source for the termites. It can be concluded that the presence of termite mounds, which constitute dominant micro-relief features in savanna ecosystems where surface water reserves are limited, can provide useful indication of unknown underground water sources.

Nutrient cycling can be another useful implication of the abundance and regeneration of mounds. In other studies elsewhere in the tropics, it was noted that the large amount of soil material brought to the surface annually by termites contains more organic carbon and nitrogen than the surrounding soil $[64,65]$. The translocated soil material, which contains nutrients are therefore recycled at fast rates thereby creating spatial heterogeneity in nutrient contents of soils $[44,66,67]$.

\subsection{Impact of Mound on Hydraulic Conductivity}

Data on hydraulic conductivity $\left(K_{\theta}\right)$ of the mound and associated soils at the two study sites as well as calculated total porosity values are provided in Table 5. The $K_{\theta}$ for the surface soils ranged from $3.3 \times 10^{-5}$ to $5.0 \times$ $10^{-5} \mathrm{~m} / \mathrm{s}$ whereas the least conductivity values were recorded for the mound samples $\left(\leq 0.5 \times 10^{-5} \mathrm{~m} / \mathrm{s}\right)$. Conductivity values in the mounds were about 6 -fold and 10-fold lower than their associated surface soils in the Rhodic Acrisol (Toje series) and Haplic Acrisol (Adenta series), respectively. The mound in the Haplic Acrisol has relatively lower $K_{\theta}$ values compared to those of the Rhodic Acrisol. Porosity is lower in the mound samples (35.1\% - 39.6\% in the Toje series and $34.3 \%-36.2 \%$ in the Adenta series) relative to the surface samples ( $>$ $50 \%$ ). Low porosity conforms to the high bulk density which is the result of the compact nature of the mounds and subsurface, especially in the Adenta series.

Studies on termite mounds elsewhere [12,13,30,44] also indicate that water infiltration in mounds is very low as a result of low porosity caused by high bulk density and compaction. It can therefore be inferred that porosity influences transport of water in the mound and associated soils. For the mound samples in particular, this confirms evidence in this study that clay enrichment leads to decrease in pore sizes and transmission of water and subsequent greater stability of the mounds.

Hydraulic conductivity was determined for different soil-mound treatments to assess the effect of mound application on water movements thereby predict management options. Data obtained from conductivity measurements of the surface soils, which were amended with mound samples are presented in Table 6. The $K_{\theta}$ values when mound samples were packed on top of the soil column varied from $0.67 \times 10^{-5}$ to $1.19 \times 10^{-5} \mathrm{~m} / \mathrm{s}$ in the Toje series and from $0.50 \times 10^{-5}$ to $0.67 \times 10^{-5} \mathrm{~m} / \mathrm{s}$ in the Adenta series. The variation in values represents about 5-fold and 3-fold reduction in conductivity in the two respective soils following this amendment. It is apparent that the $K_{\theta}$ values for the amended soils were close to those of the mound (Table 5). When the mound samples were mixed with the surface soils, the recorded $K_{\theta}$ values ranged from 2.20 to $3.30 \times 10^{-5} \mathrm{~m} / \mathrm{s}$ in the Toje series and 1.19 to $2.20 \times 10^{-5} \mathrm{~m} / \mathrm{s}$ in the Adenta series (Table 6). This range in $K_{\theta}$ is about 2-fold or less compared to the values of the untreated soils.

From this experiment it is apparent that hydraulic conductivity of the soils is influenced by the mound treatments. High clay content, high bulk density and low 
Table 5. Total porosity and hydraulic conductivity of the soils.

\begin{tabular}{|c|c|c|c|}
\hline Sample & Depth/Height (cm) & $\mathrm{TP}^{\dagger}(\%)$ & $K_{\theta}\left(\times 10^{-5} \mathrm{~m} / \mathrm{s}\right)$ \\
\hline \multicolumn{4}{|c|}{ Rhodic acrisol (Toje series) } \\
\hline \multicolumn{4}{|c|}{ Profile (depth in cm) } \\
\hline Ap & $0-6$ & 53.2 & $3.3 \pm 0.15$ \\
\hline $\mathrm{Au} 1$ & $6-22$ & 51.3 & $1.7 \pm 0.10$ \\
\hline Bt1 & $22-46$ & 50.9 & $1.7 \pm 0.09$ \\
\hline $\mathrm{Bt} 2$ & $46-77$ & 49.1 & $1.7 \pm 0.11$ \\
\hline $\mathrm{Bt} 3$ & $77-120$ & 47.2 & $1.7 \pm 0.08$ \\
\hline $\mathrm{BC}$ & $120-160$ & 48.7 & $1.8 \pm 0.14$ \\
\hline $\mathrm{C} 1$ & $160-196^{+}$ & 46.4 & $1.7 \pm 0.12$ \\
\hline \multicolumn{4}{|c|}{ Mound (height in $\mathrm{cm}$ from top) } \\
\hline T-M1 & $0-80$ & 38.9 & $0.50 \pm 0.03$ \\
\hline T-M2 & $80-160$ & 35.1 & $0.50 \pm 0.02$ \\
\hline T-M3 & $160-240$ & 35.5 & $0.50 \pm 0.02$ \\
\hline T-M4 & $240-320$ & 38.5 & $0.47 \pm 0.03$ \\
\hline T-M5 & $320-400$ & 39.6 & $0.50 \pm 0.02$ \\
\hline \multicolumn{4}{|c|}{ Transect (distance in $\mathbf{m})^{\ddagger}$} \\
\hline $\mathrm{T}-\mathrm{T} 1$ & 5 & 54.0 & $5.0 \pm 0.11$ \\
\hline $\mathrm{T}-\mathrm{T} 2$ & 15 & 54.3 & $5.0 \pm 0.30$ \\
\hline T-T3 & 20 & 54.7 & $5.0 \pm 0.24$ \\
\hline $\mathrm{T}-\mathrm{T} 4$ & 25 & 50.2 & $4.6 \pm 0.21$ \\
\hline T-T5 & 30 & 52.5 & $5.0 \pm 0.29$ \\
\hline T-T6 & 35 & 53.6 & $5.0 \pm 0.22$ \\
\hline \multicolumn{4}{|c|}{ Haplic Acrisol (Adenta series) } \\
\hline \multicolumn{4}{|c|}{ Profile (depth in cm) } \\
\hline Ap & $0-15$ & 50.6 & $3.3 \pm 0.14$ \\
\hline Au1 & $15-27$ & 46.4 & $1.7 \pm 0.09$ \\
\hline BA & $27-42$ & 40.0 & $1.7 \pm 0.10$ \\
\hline Bt1 & $42-60$ & 39.3 & $1.7 \pm 0.10$ \\
\hline $\mathrm{Bt} 2$ & $60-90$ & 35.5 & $1.7 \pm 0.12$ \\
\hline $\mathrm{Bt} 3$ & $90-120$ & 34.7 & $1.7 \pm 0.13$ \\
\hline $\mathrm{BC}$ & $120-150^{+}$ & 34.3 & $1.7 \pm 0.11$ \\
\hline \multicolumn{4}{|c|}{ Mound (height in cm from top) } \\
\hline A-M1 & $0-30$ & 36.2 & $0.33 \pm 0.04$ \\
\hline A-M2 & $30-60$ & 34.7 & $0.35 \pm 0.02$ \\
\hline A-M3 & $60-90$ & 34.3 & $0.33 \pm 0.03$ \\
\hline A-M4 & $90-120$ & 35.5 & $0.33 \pm 0.04$ \\
\hline A-M5 & $120-165$ & 34.0 & $0.33 \pm 0.04$ \\
\hline \multicolumn{4}{|c|}{ Transect (distance in $\mathbf{m})^{\ddagger}$} \\
\hline A-T1 & 5 & 50.9 & $3.3 \pm 0.15$ \\
\hline A-T2 & 10 & 51.3 & $1.7 \pm 0.10$ \\
\hline A-T3 & 15 & 50.6 & $1.7 \pm 0.11$ \\
\hline
\end{tabular}

${ }^{\dagger} \mathrm{TP}=$ total porosity $=[(1$-bulk density/particle density $) * 100 \%] ;{ }^{\ddagger}=$ Top soil sampled at $0-20 \mathrm{~cm}$ depth at the distance intervals in metres (between the location of mound and profile pits) starting from the profile pit i.e. $0-5 \mathrm{~m}$.
Table 6. Hydraulic conductivity of surface soils $(0-20 \mathrm{~cm}$ depth) amended with mound samples.

\begin{tabular}{ccc}
\hline Sample & Depth/Height $(\mathrm{cm})$ & $K_{\theta}\left(\times 10^{-5} \mathrm{~m} / \mathrm{s}\right)$ \\
\hline \multicolumn{3}{c}{ (a) Mound samples packed on top of soil surface } \\
Rhodic Acrisol (Toje series) \\
Transect (distance in m) ${ }^{\dagger}$ \\
T-T1 & 5 & $1.19 \pm 0.05$ \\
T-T2 & 15 & $0.83 \pm 0.04$ \\
T-T3 & 20 & $0.83 \pm 0.04$ \\
T-T4 & 25 & $0.83 \pm 0.05$ \\
T-T5 & 30 & $0.83 \pm 0.05$ \\
T-T6 & 35 & $0.67 \pm 0.03$ \\
& Haplic Acrisol (Adenta series) \\
Transect (distance in m) ${ }^{\dagger}$ & & $0.67 \pm 0.04$ \\
A-T1 & 5 & $0.50 \pm 0.03$ \\
A-T2 & 10 & $0.50 \pm 0.03$ \\
A-T3 & 15 &
\end{tabular}

(b) Mound samples mixed with soil surface

Rhodic Acrisol (Toje series)

Transect (distance in $\mathbf{m})^{\dagger}$

$\begin{array}{lcl}\text { T-M1 } & 5 & 2.20 \pm 0.11 \\ \text { T-M2 } & 15 & 2.20 \pm 0.12 \\ \text { T-M3 } & 20 & 3.30 \pm 0.14 \\ \text { T-M4 } & 25 & 2.20 \pm 0.12 \\ \text { T-M5 } & 30 & 2.20 \pm 0.09 \\ \text { T-M6 } & 35 & 2.20 \pm 0.09\end{array}$

Haplic Acrisol (Adenta series)

Transect (distance in $\mathbf{m})^{\dagger}$

$\begin{array}{lcc}\text { A-T1 } & 5 & 1.20 \pm 0.06 \\ \text { A-T2 } & 10 & 1.19 \pm 0.06 \\ \text { A-T3 } & 15 & 1.19 \pm 0.07\end{array}$

$\dagger=$ Top soil sampled at $0-20 \mathrm{~cm}$ depth at the distance intervals in metres (between the location of mound and profile pits) starting from the profile pit i.e. $0-5 \mathrm{~m}$.

porosity exhibited by the mound might have contributed to decrease in $K_{\theta}$ of the treated soils, especially when mound material is applied at the surface. Slow water movement implies better retention of water and applied nutrients $[13,30]$ and possible protection of underground water from pollution. The relatively lower hydraulic conductivities when the mound samples were treated with surface soils indicate that leaching of nutrients applied to the soil will be low. This will likely allow for greater uptake by plant roots, which will also ensure better crop performance, especially in many farming systems in Africa where soil nutrients are depleted because of short or non-existent fallow periods and inadequate application of external fertilizer by the resource-poor farmers. It was 
noted that the reduction in hydraulic conductivity as noted in this study will not increase run-off, which otherwise would have offset the benefits derived from using the mound as amendment material.

Although, measurement of other properties such as organic carbon content and aggregate stability was not included in the mound-amended soils, it possible that higher levels of these properties could have been obtained as noted in studies elsewhere [30]. A previous study on similar Acrisol by Akomaning et al., [6] provided quantitative evidence on reduced leaching of plant-available nutrients when fertilizers mixed with plant residues were applied to the soil surface. The residue provided a slow-down effect similar to the role played by the termite mound in our study.

\section{CONCLUSION}

This study has provided insight to the characteristics of termite mounds and associated soils in savanna ecosystem of Ghana. Termite mounds generally exhibited greater capacity of nutrient reserves with greater structural stability than their associated soils. The density of mounds and rate of regeneration were high. Conicallyshaped mounds were the dominant morphological features, which also recorded relatively higher organic carbon, nitrogen, available phosphorus and cation exchange capacity than the surrounding soils. Presence of low activity clays was consistent with the low ECEC and $\mathrm{pH}$ which are characteristic of the tropical environment. Total mass of mound material in the Toje series was twice that in the Adenta series because of larger amount of fine to medium sized material available for mound construction. Translocation of soil material from the subsoil by termites imparted greater stability to the mounds, which exhibited high bulk density, low porosity and hydraulic conductivity. Treatment of the soils with termite mounds reduced water movement in the surface soils compared to the non-treated soils. The effect of the treatment on water movement was more pronounced when the mound material was applied to the surface. The impact of this study lies in the potential of using readily available mounds as amendment materials to improve water retention, aggregate stability, and nutrient contents of soils and also reduce leaching of agrochemicals and risks of contamination of underground water. In semi arid savanna regions where surface water source are scarce presence of termite mounds can serve as reliable sources of local underground water.

\section{ACKNOWLEDGEMENTS}

The authors express their gratitude to the Technical staff at the Department of Soil Science, University of Ghana for their assistance during the laboratory investigations. We are grateful to Dr. Bill Dubbin,
Department of Mineralogy, Natural History Museum, London, UK, for the support which facilitated mineralogical analyses of selected soil and mound samples.

\section{REFERENCES}

[1] Sanchez, P.A. (1976) Properties and management of soils in the tropics. John Wiley and Sons, New York.

[2] Dregne, H.E. (1990) Erosion and soil productivity in Africa. Journal of Soil and Water Conservation, 45, 431436.

[3] Sanchez, P.A. and Logan, T.J. (1992) Myths and science about the chemistry and fertility of soils in the Tropics. In: Lal, R. and Sanchez, P.A., Eds., Myths and Science of Soils of the Tropics, Soil Science Society of America Special Publication No. 29, SSSA-ASA, Madison, 35-46.

[4] Henao, J. and Baanante, C.A. (1999) Nutrient depletion in the agricultural soils of Africa. International Food Policy Research Initiative, 2020 Vision, Brief No. 62, Muscle Shoals, Alabama.

[5] Nandwa, S.M. (2003) Perpectives on soil fertility in Africa. In: Gichuru, E.K., Ed., Soil Fertility Management in Africa: A Regional Perspective, Academy of Science Publishers and Tropical Soil Biology and Fertility Institute of CIAT, Nairobi.

[6] Akomaning, P.W., Adiku, S.G.K. and Dowuona, G.N. (2004) Water conservation and fertilizer leaching under different tillage practices in the semi arid zone of Ghana. In: Beukes, D., de Villiers, M., Mkhize, S., Sally, H. and van Rensburg, L., Eds., Water Conservation Technologies for Sustainable Dryland Agriculture in Sub-Saharan Africa, ARC-ISCW, Pretoria, 181-190.

[7] Lee, K.E. and Wood, T.G. (1971) Termites and soils. Academic Press, London.

[8] Jungerius, P.D., Vander Ancker, J.A.M. and Mücher, H.J. (1999) The contribution of termites to microgranular structure of soils on the Uasin Gishu Plateau, Kenya. $\mathrm{Ca}$ tena, 34, 349-363. doi:10.1016/S0341-8162(98)00106-4

[9] Bignell, D.E. and Eggleton, P. (2000) Termites in ecosystems. In: Abe, T., Higashi, M. and Bignell, D.E., Eds., Termites: Evolution, Sociality, Symbiosis, Ecology, Kluwer Academic Press, Dordrecht.

[10] Jiménez, J.J. and Decaëns, T. (2006) Chemical variations in the biostructures produced by soil ecosystem engineers. Examples from the neotropical savannas. European Journal of Soil Biology, 42, S92-S102. doi:10.1016/j.ejsobi.2006.07.040

[11] Kaschuk, G., Santos, J.C.P., Almeida, J.A., Sinhorati, D.C. and Berton-Junior, J.F. (2006) Termite activity in relation to natural grassland soil attributes. Science and Agriculture (Piracicaba, Brazil), 63, 583-588.

[12] Le'onard, J. and Rajot, J.L. (2001) Influence of termites on runoff and infiltration: Quantification and analysis. Geoderma, 104, 17-40. doi:10.1016/S0016-7061(01)00054-4

[13] Jouquet, P., Tessier, T. and Lepage, M. (2004) The soil structural stability of termite nests: Role of clays in Macro- 
termes bellicosus (Isoptera, Macrotermitinae) mound soils. European Journal of Soil Biology, 40, 23-29.

doi:10.1016/j.ejsobi.2004.01.006

[14] Ackerman, I.L., Teixeira, W.G., Riha, S.J., Lehmann, J. and Fernandes, E.C.M. (2007) The impact of moundbuilding termites on surface soil properties in a secondary forest of Central Amazonia. Applied Ecology, 37, 267276. doi:10.1016/j.apsoil.2007.08.005

[15] Lal, R. (1988) Effects of macrofauna on soil properties in tropical ecosystems. Agriculture, Ecosystems and Environment, 24, 101-116. doi:10.1016/0167-8809(88)90059-X

[16] Lavelle, P.M., Dangerfield, C., Fragoso, V., Eschnebrenner, D.L., Hernadez, B. and Pashanari, B.L. (1994) The relationship between soil macrofauna and tropical soil fertility. In: Woomer, P.L. and Swift, M.J., Eds., The Biological Management of Tropical Soil Fertility, Wiley Publication, New York, 136-169.

[17] Jouquet, P., Mamou, L., Lepage, M. and Velde, B. (2002) Effect of termites on clay minerals in tropical soils: Fungus-growing termites as weathering agents. European Journal of Soil Science, 53, 1-7. doi:10.1046/j.1365-2389.2002.00492.x

[18] Manuwa, S.I. (2009) Physico-chemical and dynamic properties of termite mound soil relevant in sustainable food production. African Crop Science Conference Proceedings, 9, 365-369.

[19] Kebede, F. (2004) Use of termite mound for mineral exploration. Journal of African Earth Science, 41, 101-103. doi:10.1016/j.jafrearsci.2004.06.002

[20] Mege, D. and Rango, T. (2010) Permanent groundwater storage in basaltic dyke features and termite mound viability. Journal of African Earth Science, 57, 127-142. doi:10.1016/j.jafrearsci.2009.07.014

[21] Dangerfield, J.M., Mccarthy, T.S. and Ellery, W.N. (1998) The mound-building termite Macrotermes michaelseni as an ecosystem engineer. Journal of Tropical Ecology, 14, 507-520. doi:10.1017/S0266467498000364

[22] Turner, J.S. (2000) Architecture and morphogenesis in the mound of Macrotermes michaelseni (Sjostedt) (Isoptera: Termitidae macrotermitinea) in northern Namibia. Cimbebasia, 16, 143-175.

[23] Wood, T.G. (1996) The agricultural importance of termites in the tropics. Agricultural Zoology Reviews, 7, 117150.

[24] Lobry De Bruyn, L.A. and Conacher, A. (1990) The role of termites and ants in soil modification: A review. Australian Journal of Soil Research, 28, 55-93.

[25] Holt, J.A. and Lepage, M. (2000) Termites and soil properties. In: Abe, T., Bignell, D.E. and Higashi, M., Eds., Termites: Evolution, Sociality, Symbioses, Ecology, Kluwer Academic Publishers, Dordrecht, 389-408.

[26] Azeredo, G., Morel, J.C. and Barbosa, N.P. (2007) Compressive strength of earth mortars. Journal of Urban and Environmental Engineering, 1, 1-4. doi:10.4090/juee.2007.v1n1.026035

[27] Abe, S.S., Yamamoto, S. and Wakatsuki, T. (2009) Soilparticle selection by the mound-building termite Macrotermes bellicosus on a sandy loam soil catena in a Nige- rian tropical savanna. Journal of Tropical Ecology, 25, 449-452. doi:10.1017/S0266467409006142

[28] Millogo, Y., Hajjaji, M. and Morel, J.C. (2011) Physical properties, microstructure and mineralogy of termite mound material considered as construction materials. Applied Clay Science, 52, 160-164.

doi:10.1016/j.clay.2011.02.016

[29] Endubu, M., Kombele, B.M., Litucha, B.M. and Mambani, B. (1992) Prospects for using termite mounds to improve the fertility of Tropical soils: Pot experiments. Tropicultura, 10, 51-54.

[30] Garba, M., Cornelis, W.M. and Steppe, K. (2011) Effect of termite mound material on the physical properties of sandy soil and on the growth characteristics of tomato (Solanum lycopersicum L.) in semi-arid Niger. Plant and Soil, 338, 451-466. doi:10.1007/s11104-010-0558-0

[31] Watson, J.P. (1977) The use of mounds of the termite Macrotermes falciger (Gerstacker) as a soil amendment. Journal of Soil Science, 28, 664-672. doi:10.1111/j.1365-2389.1977.tb02273.x

[32] Wood, T.G., Johnson, R.A. and Anderson, J.M. (1983) Modification of the soil in Nigerian savanna by soil feeding Cubitermes (Isoptera, Termitidea). Soil Biology and Biochemistry, 15, 575-579. doi:10.1016/0038-0717(83)90052-4

[33] Benzie, J.A.H. (1986) The distribution, abundance, and the effects of fire on mound building termites (Trinervitermes and Cubitermes spp., Isoptera: Termitidae) in northern guinea savanna West Africa John A.H. Benzie. Oecologia, 70, 559-567. doi:10.1007/BF00379904

[34] Kortatsi, B.K. (1994) Future groundwater resources at risk. IAHS Publication No. 222, IAHS, Helsinki.

[35] Dapaah-Siakwan, S. and Gyau-Boakye, P. (2000). Hydrogeologic framework and borehole yields in Ghana. Hydrogeology Journal, 8, 405-416. doi:10.1007/PL00010976

[36] Blake, G.R. and Hartge, K.H. (1986) Bulk density. In: Klute, A., Ed., Methods of Soil Analysis, Part 1-Physical and Mineralogical Methods, 2nd Edition, Agronomy Monograph 9, American Society of Agronomy-Soil Science Society of America, Madison, 363-382.

[37] Day P.R. (1965). Particle fractionation and particle size analysis. In: Black, C.A., Ed., Methods of Soil Analysis, American Society of Agronomy, Madison, 545-567.

[38] Bremner, J.M. and Mulvaney, C.S. (1982) NitrogenTotal. In: Page, A.L., Miller, R.H and Keeney, D., Eds., Methods of Soil Analysis, Part 2-Chemical and Microbiological Properties, 2nd Edition, American Society of Agronomy-Soil Science Society of America, Madison, 595-622.

[39] Bray, R.H. and Kurtz, L.T. (1945) Determination of total organic and available forms of phosphorus in soils. Soil Science, 59, 39-45. doi:10.1097/00010694-194501000-00006

[40] Thomas, G.W. (1982) Extractable cations. In: Page, A.L., Miller, R.H. and Keeney, D., Eds., Methods of Soil Analysis, Part 2-Chemical and Microbiological Properties, 2nd Edition, American Society of Agronomy-Soil Science Society of America, Madison, 159-165. 
[41] Middleton, H.E. (1930) Properties of soil which influence erosion. USDA Technical Bulletin, 178, 1-16.

[42] Adekayode, F.O. and Ogunkoya, M.O. (2009) Comparative study of clay and organic matter content of termite mounds and the surrounding soils. African Crop Science Conference Proceedings, 9, 379-384.

[43] Jouquet, P., Bottinelli, N., Lata, J-C., Mora, P. and Caquineau, S. (2007) Role of the fungus-growing termite Pseudacanthotermes spiniger (Isoptera, Macrotermitinae) in the dynamic of clay and soil organic matter content. An experimental analysis. Geoderma, 139, 127-133. doi:10.1016/j.geoderma.2007.01.011

[44] Arshad, M.A. (1982) Influence of the termite Macrotermes michaelseni (Sjöst) on soil fertility and vegetation in a semi-arid savanna ecosystem. Agro-Ecosystems, 8, 4758. doi:10.1016/0304-3746(82)90014-2

[45] Sileshi, G.W., Arshad, M.A., Konate', S. and Nkunika, P.O.Y. (2010) Termite-induced heterogeneity in African savanna vegetation: Mechanisms and patterns. Journal of Vegetation Science, 21, 923-937. doi:10.1111/j.1654-1103.2010.01197.x

[46] Fall, S., Brauman, A. and Chotte, J.L. (2001) Comparative distribution of organic matter in particle and aggregate size fraction in the mounds of with different feeding habitats in Senegal: Cubitermes niokoloensis and Macrotermes bellicosus. Applied Soil Ecology, 17, 131-140. doi:10.1016/S0929-1393(01)00125-1

[47] Gillman, L.R., Jeffries, M.K. and Richard, G.N. (1972) Non-soil constituents of termite (Coptotermes acinaciformes) mounds. Australian Journal of Biological Sciences, 25, 1005-1013.

[48] Gupta, S.R., Rajvanshi, R. and Singh, J.S. (1981) The role of the termite Odontotermes gurdaspurensis in plant decomposition in a tropical grassland. Pedobiologia, 22, 254-261.

[49] Alain, B. (2000). Effect of gut transit and mound deposit on soil organic matter Transformations in the soil feeding termite: A review. European Journal of Soil Biology, 36, 117-125. doi:10.1016/S1164-5563(00)01058-X

[50] Alain, B., Jean-Luc, C. and Saliou F. (2001) Comparative distribution of organic matter in particle and aggregate size fractions in the mounds of termites with different feeding habits in Senegal: Cubitermes niokoloensis and Macrotermes bellicosus. Applied Soil Ecology, 17, 131140. doi:10.1016/S0929-1393(01)00125-1

[51] Tathiane, S.S., Carlos, E.G.R.S., Leila de Souza, L., Helga, D.A., Joao, H.M.V., Manoel, R.F. and Teresa, T.G. (2008) Chemical, properties physical and micromorphological properties of termite mounds and adjacent soils along a toposequence in Zona da Mata, Minas Gerais State, Brazil. Catena, 76, 107-113.

[52] Landon, J.R. (1984) Booker tropical soils manual. Booker Agriculture International Ltd., Longman.

[53] Brammer, H. (1967) Soils of the Accra plains. Memoir No. 3, Soil Research Institute, Kumasi.
[54] Pomeroy, D.E. (1978) The abundance of large termite mounds in Uganda in relation to their environment. Journal of Applied Ecology, 15, 51-63. doi:10.2307/2402920

[55] Sheik, K.H. and Kayani, S.A. (1982) Termite-affected soils in Pakistan. Soil Biology and Biochemistry, 14, 359364. doi:10.1016/0038-0717(82)90006-2

[56] Six, J., Feller, C., Denef, K. and Ogle, S.M. (2002) Soil organic matter, biota and aggregation in temperate and tropical soils-Effect of no-tillage. Agronomie, 22, 755775. doi:10.1051/agro:2002043

[57] Six, J., Bossuyt, H., Degryze, S. and Denef, K. (2004) A history of research on the link between (micro) aggregates, soil biota, and soil organic matter dynamics. Soil and Tillage Research, 79, 7-31. doi:10.1016/j.still.2004.03.008

[58] Bronick, C.J. and Lal, R. (2005) Soil structure and management: A review. Geoderma, 124, 3-22. doi:10.1016/j.geoderma.2004.03.005

[59] Dowuona, G.N.N., Adjetey, E.T., Nartey, E.K., Adjadeh, T.A. and Heck. R. (2011) Carbon accumulation and aggregate stability in an Acrisol under different fallow management in Ghana. Journal of Soil Science and Environmental Management, 2, 393-403.

[60] Garnier-Sillam, E. and Harry, M. (1995). Distribution of humic compounds in mounds of soil-feeding termite species of tropical rainforests: Its influence on soil structural stability. Insectessociaux, 42, 167-185. doi:10.1007/BF01242453

[61] Semhi, K., Chauduri, S., Clauer, N. and Boeglin, J.L. (2008) Impact of termite activity on soil environment: A perspective from their soluble chemical components. International Journal of Environmental Science and Technology, 5, 431444.

[62] Nye, P.R. (1955) Some soil forming processes in the humid tropics. Journal of Soil Science, 6, 73-83. doi:10.1111/j.1365-2389.1955.tb00831.x

[63] Grimaldi, D. and Engel, M.S. (2005) Evolution of the Insects. Cambridge University Press, Cambridge.

[64] Hewitt, P.H., van der Westhuizen, M.C., de, K., van der Linde, T.C. and Mitchell, J. (1990) The dry matter, energy and nitrogen budget of the harvester termite Hodotermes mossambicus (Hagen). South African Journal of Science, 86, 30-34.

[65] Ndiaye, D., Lepage, M., Sall, C. and Brauman, A. (2004) Nitrogen transformations associated with termite biogenic structures in a dry savanna ecosystem. Plant and Soil, 265, 189-196. doi:10.1007/s11104-005-0892-9

[66] Bagine, R.K.N. (1984) Soil translocation by termites of the genus Odontotermes (Holmgren) (Isoptera: Macrotermitinae) in an arid area of Northern Kenya. Oecologia, 64, 265-266. doi:10.1007/BF00376880

[67] Mora, P., Seuge, C., Chotte, J.L. and Rouland, C. (2003) Physico-chemical typology of the biogenic structures of termites and earthworms: A comparative analysis. Biology and Fertility of Soils, 37, 245-249. 